\title{
Egy „furcsa ember” - Selye Jánosról magyar kapcsolatainak tükrében
}

\author{
Szabó Katalin dr. \\ Semmelweis Orvostörténeti Múzeum Könyvtár és Levéltár, Budapest
}

\begin{abstract}
Selye János egyaránt mély benyomást tett mind a magyar orvosi, tudományos, mind pedig a közéletre. 1938-ban értekezett először az Orvosi Hetilapban az alarm reakcióról. A háború utáni magyar kapcsolatai is széles körüek voltak és kiterjedtek nemcsak a hazai előadások és tudományos publikációk, hanem a magyar hallgatók montreali képzésére is. A gazdag levéltári anyag feltárása folyamatban van és minden bizonnyal izgalmas adatokat tartogat még számunkra. Orv. Hetil., 2015, 156(35), 1436-1440.
\end{abstract}

Kulcsszavak: Selye János, stressz, magyar vonatkozások

\section{A peculiar man - about Hans Selye in the mirror of his Hungarian connections}

Hans Selye made a great impact on the Hungarian medical, scientific and public life. His first Hungarian publication about the alarm-reaction appeared 1938 in the Orvosi Hetilap. His Hungarian relationship was quite extensive after the war as he published, gave lectures, and accepted Hungarian students for specialized training in his Canadian institute saw. The rich documents in archives about Selye are currently being processed and those will surely shed light on Selye's life in further details.

Keywords: Hans Selye, stress, Hungarian relations

Szabó, K. [A peculiar man - about Hans Selye in the mirror of his Hungarian connections]. Orv. Hetil., 2015, $156(35), 1436-1440$.

(Beérkezett: 2015. június 4.; elfogadva: 2015. július 2.)

„Selye János furcsa ember volt. Egyik lábával a XIX. században - a nagy felfedezések korában -, a másikkal talán a XXI-ben állt” [1] - írta róla egyik volt tanítványa, Bertók Loránd. És valóban: életmúve bizonyítja az állítást. A stresszkoncepció megalkotását talán Harvey (15781657) felfedezésével, felfedezésének körülményeivel lehetne összevetni, hiszen hasonlatosan Harvey-hoz, Selyét is sokan támadták, és sokan vitatták el felfedezésének elsőségét. Maga Selye (1907-1982) is alátámasztja ezt, hiszen a tudományos felfedezésekról szólva írja, hogy „nem az a lényeges, hogy valamit elsőnek lássunk meg, hanem az, hogy szilárd kapcsolatot teremtsünk az előzőleg megismert és az eddig ismeretlen között. Ez a tudományos felfedezés ábécéje" [2]. A stresszkoncepcióval egy új szemléletmódot adott az orvostudománynak, és új távlatokat nyitott a betegségek okait, következményeit kutatók számára. Tulajdonképpen ezzel tárta szélesre az ajtót a XXI. századi kutatások előtt.

Talán furcsa volt azért is, mert szerette a kutatásait, eredményeit belehelyezni a történeti időbe, de ugyanak- kor a folyamatban lévő, kortárs kutatások hálójába is. Éppen ezért tekintett vissza gyakran a nagy elődökre, nemcsak az általa is gyakran emlegetett Cannonre (1871-1945) vagy Claude Bernardra (1813-1878), hanem szívesen idézett olyanokat is, akiket talán kevés eséllyel hoztak volna összefüggésbe a stresszel. Ilyen különlegesség valószínúleg Thomas Blizard Curling (1811-1888), angol sebész is, akire Selye hivatkozik. Ö már 1842-ben leírt olyan gyomorfekélyt, ami égési sebek alkalmával, tehát stressz hatására keletkezett [3]. A kortárs kutatási eredmények feltérképezését is fontosnak tartotta. Kenéz János (1908-1984) jegyzi meg méltatásában, hogy Selye 1950-ben megjelent Stress címú könyve 800 oldalt tesz ki, amiből 200 oldalt foglalt el a bibliográfia, becslései szerint nagyjából 4000 munkát említve, „ebből ugyancsak becslés szerint saját munkái 200-at tesznek ki, ebben a számban azonban nem szerepelnek azok a munkák, melyekben Selye társszerző, mivel ezek nem az S. betü alatt szerepeltek" [4]. 


\section{Selye magyar kapcsolatai a háború elő́tt}

Ebben a nagyon sűrün szövött hálóban rajzolódnak ki azok a kapcsolatok is, amelyek Selyét a magyar tudományos világhoz füzték, annak ellenére, hogy tanulmányai és kutatói pályája is külföldhöz kötötték. Ugyan a prágai német egyetemen képezték orvossá, de ott, a kiskomlósi születésư Arthur Biedl (1869-1933), az endokrinológiai ismereteket elsőként rendszerbe foglaló patológus mellett tanulta meg az experimentális munka lényegét. Amint egyik, Kenéz Jánoshoz szóló levelében írja, híres könyvtárának alapjait is Biedlnek köszönheti: „Véletlenül én örököltem azt a különlenyomat-gyújteményt, amelyből ezt a múvet (ti. az Innere Secretion címűt) öszszeállította. 30.000 separatumot tartalmazott, ezt fejlesztettem a világ legnagyobb belső szekréciós különlenyomat-gyújteményévé, amely jelenleg mintegy 750.000 különlenyomatot számlál” [5].

Selye a stresszelmélet megalkotása, az adaptációs szindróma leírása és Nature-beli 1936-os megjelenése után két évvel már az Orvosi Hetilap hasábjain értekezett az alarm reakcióról. Szerzőtársa J. S. L. Browne (19041984) mellett Karády István (1904-1974), a cikket a montreali McGill Egyetemről jegyezték. Amint írták, vizsgálataik megértése céljából szükségesnek tartották ismertetni az alarm reakció lényegét, „annál is inkább, mert az alarm reactio fogalma Európában még csak kevéssé ismeretes" [6]. Egyelőre nem derült ki, hogy Karády István kutatott-e a McGill Egyetemen Selyével vagy csak a szerzőségi adatoknál szerepelnek megtévesztően az információk, az azonban biztos, hogy Karády István szívén viselte a stressz népszerüsítését; így az alarm reakcióról 1939-ben tartott előadást a Ferenc József Tudományegyetem Baráti Egyesülete Orvosi Szakosztályának decemberi ülésén [7].

Verzár Frigyes (1886-1979) vagy Beznák Aladár (1901-1959) munkáira rendszeresen hivatkozott Selye, személyesen is ismerte a legnagyobb magyar endokrinológusokat. Dr. Szállási Árpád (1930-2012) egy, Selyéről írt cikkében mondta el a következő történetet: „A nagyemlékű Went István fiziológus professzor mesélte annak idején, hogy a harmincas évek elején egy Zürichben tartott élettani konferencián (melyet a Debrecenből elszármazott Verzár Frigyes professzor szervezett) feltünt egy igen élénk érdeklődésú fiatal kutató, aki mindig azon a nyelven szólott hozzám, amelyen az előadás elhangzott. Mikor Went professzor kiléte felől érdeklődött meglepő módon, kifogástalan magyar nyelvű választ kapott. Vagyis: »Selye János vagyok, komáromi fiú, nyugodtan beszéljünk magyarul " [8].

A II. világháború befejezése után, különösen az 50-es évektől, a stressz megkerülhetetlen témává vált. A témához kapcsolódó hazai kutatásokról az Orvosi Hetilap hasábjain olvashattak az érdeklődők. Ilyenek voltak például a Szegedi Tudományegyetemen $[9,10]$ vagy a Fővárosi Péterfy Sándor Utcai Kórház-rendelőben [11] folyó kutatásokról szóló beszámolók, amelyek hivatkozásaiban rendszeresen olvashatjuk Selye nevét és múveit.

\section{Selye a háború utáni Magyarországon}

Selye stresszkoncepcióját azonban számos bírálat is érte. Nálunk ezek a kritikák gyakran álltak ideológiai alapokon, mert úgy értették, hogy Selye elmélete ellentmond a pavlovi nervizmus „eszméjének”. Ilyen például Arató Emil (1885-1978) hozzászólása a témához a sport és a stressz kapcsolata ürügyén: „Tisztában vagyunk azzal, hogy a nyugat szakirodalmában miért foglalkoznak anynyit a stress-szel, amikor a nervizmus részére alig van szavuk. [...] Nem reánk tartozik annak elbírálása, hogy a kórélettani szemléletben szükség van-e a 'stress-re', amikor az orvostudomány a nervizmus elméletében határozott és világos útmutatóval rendelkezik és vajjon helyese, hogy előadásainkon és cikkekben gyakran hivatkoznak reá" [12]. Ennél talán explicitebben fejezte ki a törekvést Hetényi Géza, aki a következőket írta: „A pavlovi tanok és ezeknek a keretén belül a nervizmus eszméje KeletNémetországban is csupán a második világháború befejezése után hatoltak be az orvostudományba. Minél szélesebb körben való elterjesztésüket az ottani vezető körök minden eszközzel igyekeztek előmozdítani és ezt szovjet könyvek fordításán, tudósok meghívásán és a felsőbb idegtevékenység vizsgálatára alkalmas berendezések létesítésén kívül évente rendezett nemzetközi találkozón kívánják elérni” [13].

Selye 1960-ban Bajusz Eörssel (1926-1973) együtt jegyzett cikkében törekedett a félreértések eloszlatására. Amint írták: „Szeretnénk [...] elősegíteni annak a félreértésnek eloszlatását, mely arra vezetett, hogy a szervezet védekező reakcióinak endokrin mechanizmusát vizsgáló kutatásaink syntézisét, egyesek egyenesen szembeállították a pavlovi physiologia nagy jelentőségú tanításával" [14]. Ez a tanulmány tulajdonképpen elő is készítette Selye első, háború utáni útját Magyarországra. Az itt-tartózkodást és a programot Babics Antal (19021992), a Magyar Tudományos Akadémia osztálytitkára szervezte. Az előkészületek iratanyagából kitűnik, hogy dr. Petri Gábor, a Szegedi Orvostudományi Egyetem rektora április 23-án kelt, a Tudományos Akadémiához intézett levelében - nyilván a Selye Jánossal és intézetével fenntartott régi kapcsolat okán - szerette volna meghívni a professzort egy szegedi előadásra [15], azonban ezt akkor az Akadémia elutasította. 1960. május 20-án délután 5 órakor került sor az egyetlen, ekkori látogatásán elhangzott előadásra az Akadémia 300-as termében.

Selye professzor 1965-ben is a Magyar Tudományos Akadémián tartott nagy sikerű előadást. Az Akadémia díszterme zsúfolásig megtelt, ahol Babics Antal köszöntötte a vendéget. Az előadás az éppen aktuális kutatások köré épült és érintette - a plurikauzális betegségekről szóló bevezető után - az adaptációs rendszer betegségeit és a calciphylaxist. Az előadás végén a közönség állva, lelkesen ünnepelte Selye Jánost [16]. A világhírü vendéget a Magyar Tudományos Akadémia Kísérleti Orvosi Kutatóintézetében is fogadták, ahol Stark Ervinnel (1922-1995), az intézet igazgatójával tekintette meg a kutatóhelyet. 
A professzor következő látogatása 1968-ra esett. Ekkor már, nyilván a politikai enyhülés következményeként és a kiterjedt tudományos kapcsolatok révén, az ország orvosegyetemein, illetve a szombathelyi Markusovszky Kórházban tett látogatást és tartott előadásokat.

Selye ausztriai vendégeskedése után, május 9-én érkezett a rábafüzesi határátkelőhöz, ahol a sajtó nagy érdeklődése mellett, $d r$. Molnár László megyei föorvos és $d r$. Solymoss Béláné, a megyei kórház adjunktusa várta. A tudós a Magyar Tudományos Akadémia meghívására érkezett Magyarországra, Szombathelyre a helyi kórház invitálta. A kórházban tett látogatást és előadást befolyásolhatta az a tény is, hogy Solymoss Béla (1924-2012), a központi laboratórium fooorvosa immár másodszor nyert ösztöndíjat a montreali intézetbe. A városi vezetőkkel történt találkozás után lépett Selye a zsúfolásig megtelt, még a folyósón is álldogáló nagyszámú közönség elé.

A professzor köztudomásúan jó előadó volt. Már az első mondatokkal képes volt lebilincselni a közönséget. Így volt ez ekkor is: „Nem tudom, hogyan szokás Önöknél hivatalos formulák szerint köszönteni ilyen népes, kedves hallgatóságot. Ezért engedjék meg, hogy én így köszöntsem Önöket, drága szülőhazám lakóit: szervusztok, magyarok!” [17] - mondta a köszöntőben. Az előadás a továbbiakban a stressz és a cardiovascularis betegségek kapcsolatáról szólt és hatalmas sikert aratott. Zárásképpen $d r$. Gelencsér József, a kórház megbízott igazgatója Markusovszky-emlékplakettel, dr. Orsós Sándor igazgatóhelyettes pedig egy Szombathelyről szóló könyvvel köszönte meg az előadást és a látogatást. A kórház mai napig őrzi vendégkönyvében Selye János bejegyzését: „A Markusovszky Kórháznak sok sikert kívánok és a Solymossékért nagyon hálás vagyok" [18].

Az előadás-sorozat Budapesten folytatódott. Az Orvosegyetem címú lapban $d r$. Matos Lajos emlékezett meg az eseményröl „Prof. Selye János és az elöadás müvészete” címú írásában. Már a címből is kitünik, hogy a cikk, a tudományos eredmények mellett, Selye egyik nagy adottságára, rétori képességeinek elemzésére helyezte a hangsúlyt. Selye személyes elemmel kezdte előadását: „Elutazásom előtt Montrealban magyar asszisztenseim összeültek és egy szép bevezetőt írtak a mai előadáshoz. Én ezt a bevezetőt az úton elvesztettem. Nem tudok, hát mást mondani, mint azt, hogy: Szervusztok! Hazajöttem!" [19]. Mint Matos doktor fogalmazott, a captatio benevolentiae olyan jól sikerült, hogy az üdvözlő tapsvihar és az elhangzott első mondatok után a közönség újra ovációba kezdett. Persze az elemzések azzal is foglalkoztak, hogy a természetes előadói vénán túl, mitől hatásosak és sikeresek az előadások. Legtöbbször a világos, egyszerü fogalmazást, a közérthetőséget, a spontán közvetlenséget, a jól felépített szerkezetet szokták említeni, ami a közönségre lenyügözően hatott. Előadásában az akkor újnak számító szemléltetés is figyelemre méltónak számított. Mondandóját soha nem olvasta, stílusa friss, új színt hozott a magyar tudományos közéletbe.
Az előadókörút harmadik állomása Debrecen volt, ahol a szülészeti klinika amfiteátrumában tartotta meg „A stressz és a gyulladás” címú előadását. Debrecenben Kesztyüs Loránd (1915-1979) immunológus-patofiziológus professzor munkája tett Selyére mély benyomást.

A debreceni látogatás Szegeden folytatódott, ahová május 13-án érkezett, és ahol a Szemészeti Klinikán tartott rendkívüli tudományos ülés keretében szólt a közönséghez. Mellette ezen a délutánon $H$. J. Wespi svájci nőgyógyászprofesszor, az aaraui Frauenklinik des Kantonsspitals föorvosa tartott ismertetőt munkájáról.

A szegedi Dél-Magyarország címú lap interjújából kiderült, hogy Selye magyarországi utazását a kapcsolatépítés szempontjából is fontosnak tartotta, hiszen nagyon jó véleménnyel volt a magyar orvosokról, ahogyan ebben a riportban nyilatkozott: „... büszkék lehetünk a magyar orvostudományra [...] s bár nem olyan széles körü, mint például Amerikában, ám minőségileg elsőrendü" [20]. Szegeden Julesz János belgyógyász, endokrinológus munkáját különösen nagyra értékelte, és megemlítette, mennyire becsülte ifj. Jancsó Miklós (1903-1966) professzort, akit betegsége és halála akadályozott meg abban, hogy a Montreali Egyetem vendégprofesszora legyen.

Pécsre május 14-én látogatott el Selye János, ahova Barta Ottó (1916-1992) professzor kezdeményezésére, Flerkó Béla (1924-2003) anatómus, az Orvosi Szakosztály elnöke hívta meg. Ehhez a meghíváshoz, mint ahogyan a többi egyetemen tartott előadáshoz is, az Egészségügyi Minisztérium engedélyét kellett kérni. Selye Szegedről érkezvén, a pécsi Anatómiai Intézetben tett látogatást, majd a rektori hivatalban üdvözölte Boros Béla (1903-1992) rektort. Az ebéden csak néhány professzor vett részt: Selye mellett Bertók Loránd, Selye kísérője, a rektor, Rombányi György (1905-1991), Barta, Flerkó és Lissák Kálmán (1908-1982) professzorok. A városnézési program után következett az előadás, amelyet több országos napilap érdeklődése mellett a Magyar Televízió is rögzített. A terem Pécsett is zsúfolásig megtelt. A közönség körében az orvosok mellett laikusok is szép számmal akadtak. A látogatásról a részletes beszámolót Boros rektor készítette, az Egészségügyi Minisztérium Nemzetközi Kapcsolatok Főosztálya felszólítására.

A szívélyes pécsi fogadtatást később Selye nevében Bertók Loránd köszönte meg. Mint írta: „Selye profeszszor szerencsésen hazaérkezett Montrealba, és nagyon hálásan emlékezik levelében a Pécsett töltött rövid időre. Nagy örömére szolgált, hogy megismerkedhetett Professzor Urral, és találkozhatott Lissák, Romhányi, Flerkó és Barta professzor urékkal. Nagyon örült, hogy láthatta a Halász-féle patkánymútétet és várja a SzentágothaiFlerkó-Halász-Mess-féle monográfiát” [21].

Selye következő látogatásai az 1970-es évekre esnek. Ennek az időszaknak meghatározó témája volt Selye esetleges hazatelepülése nyugdíjba vonulása után, illetve könyvtárának a sorsa. Érdekes, hogy a hazatérés már a 
hatvanas évek végén foglalkoztatta, hiszen már 1968-as látogatása alkalmával azt nyilatkozta, hogy szívesen hazatérne, „ha a munkához szükséges körülmények rendelkezésemre állnak. Magyarságomra büszke vagyok, anyanyelvemet olvasással igyekszem ápolni, s valahogy úgy vagyok ezzel, hogy az első gyerekem után még három született, de azokat sem tudtam jobban szeretni, mint az elsőt. Kanadát sem jobban, mint Magyarországot" [20].

A következő magyarországi meghívást Barta János, Magyarország ottawai nagykövete intézte, akit azzal is megbíztak, hogy a hazatelepülés kérdésében is tájékozódjon a professzortól. (Selye nyugdíjazásának várható időpontja 1976 volt.) Barta arról is informálta Selyét, hogy dr. Rosta Endre, a Kulturális Kapcsolatok Intézetének igazgatója is fogadja majd Budapesten. Rostát bízták meg azzal, hogy foglalkozzon Selye hazatelepülésének kérdésével. Selye 1973. november 18-án érkezett meg Ferihegyre, ahol Stark Ervin (1922-1995) akadémikus, a Magyar Tudományos Akadémia Kísérleti Orvosi Kutatóintézetének igazgatója fogadta. Innen a Gellért Szállóba mentek, ahol a professzor szállása volt és ahol volt tanítványai fogadást rendeztek számára. A későbbi nagyköveti jelentésből kitûnik, hogy Selyét nagyon mélyen érintette tanítványai gesztusa is: „Meghatottan vette tudomásul, hogy megérkezésekor népes delegáció várta a repülőtéren, akik között a hivatalos személyek mellett volt tanitványai is - hosszabb, vidékről történő felutazás után - találkoztak vele a repülőtéren. Ugy érzi, ez nem mint tudós iránti tisztelet, hanem meleg emberi szeretetnek tudható be. Hasonlóan nagy elismeréssel beszélt a Gellértben volt tanitványai által szervezett vacsoráról" [22].

Másnap, november 19-én 10 órakor fogadta $d r$. Tímár Lászlót, akivel könyvének, a „Stress withouth Distress”-nek a magyar nyelvű kiadását beszélték meg. Rosta Endrével 12 órakor találkozott, majd ebéd után megbeszélést tartottak Erdey-Grúz Tiborral (1902-1976), a Magyar Tudományos Akadémia elnökével. Az előadásra, amelynek címe „A stressz kutatásának mai állása” volt, 16 órakor került sor az Akadémián, amin szigorúan csak meghívóval lehetett részt venni. Az előadás után a Magyar Tudományos Akadémia Orvosi Osztálya a Tudósklubban, a Zöld Szobában fogadást adott Selye tiszteletére. A professzor másnap reggel folytatta útját Berlinbe.

1974-es látogatása könyvei nagy sikerének köszönhető, hiszen Selye három, magyarra fordított könyvének példányszáma ekkorra elérte a százezret. A látogatás programját az Akadémiai Kiadó és a Magyar Tudományos Akadémia szervezte. A sajtótájékoztató után a szerző dedikálta könyveit. Nem került minden várakozó sorra, hiszen a kígyózó sor két háztömbnyire húzódott a bejárattól.

Rosta Endre szeptember 27-én találkozott Selyével, amikor is elsősorban könyvtára sorsáról beszéltek. Az akkori álláspont szerint Magyarország nem tudta vállalni a könyvtárral járó költségeket [22].
A professzor nemcsak a szakmai sikereket, a szakmához szóló publikációkat tartotta fontosnak. Selye azok közé az igazán nagy tudósok közé tartozott, akik tudtak és akartak is a tudományról, az orvoslásról mindenki számára érthető nyelven, olvasmányosan és érdekfeszítően beszélni. Ezzel az intencióval jelent meg 1956-ban, angol nyelven, világsikert elért, méltán népszerü munkája, a „Stress of Life”. Számos nyelvre lefordították, és Selye 1960-ban kezdett levelezni a Magyar Tudományos Akadémiával annak érdekében, hogy a könyv magyarul is megjelenhessen. Az orvos, akadémikus Lissák Kálmán - aki egyébként Selye több, magyar nyelven megjelent munkájához is írt előszót - a következőképpen jellemzi a könyvet: „A könyv közérthető formában, didaktikus ábráival világos összefoglalását adja a szerző több mint két évtizedes kutatásai ma már valóban értékelhető eredményeinek. Könnyen érthető és amellett élvezetes írásmódjával nemcsak a szakembereknek szól, hanem a müvelt magyar közönség érdeklődésére is méltán számot tarthat, mert egy érdekes, lebilincselő egyéniségű kutató izgalmas életútját bemutatva vezet el a sok nehézséggel küzdő, de mégis az élet legszebb és egyben legnemesebb örömeit kínáló laboratóriumi kutatások világába” [23].

\section{Selye Magyarország és Kanada viszonyában}

A Selyével kapcsolatos gazdag iratanyag - látogatásai mellett - két területre terjed ki. Az egyik az ösztöndíjasok ügye, akik mindig nagy számban voltak jelen Selye intézetében, a másik pedig Selye hazatelepülési szándékának és ezzel kapcsolatban felajánlott könyvtárának az ügye.

Az ösztöndíjasok kiválasztásánál szakmai, kultúr- és tudománypolitikai szempontok rajzolódnak ki. A hazatelepülés ügyét igyekeztek politikai kérdésnek feltüntetni, de mint az eddig feltárt anyagból kiderül, volt benne erős szakmai féltékenység is.

Míg Selye Magyarországhoz fúződő viszonyában felsejlik egy erős érzelmi szál; az akkori magyar politikai hatalom a vele fenntartott viszonyból itthon a hatalom számára fontos közéleti hasznot szeretett volna kovácsolni, nemzetközi színtéren kapcsolatokat, elismerést remélt. Ez utóbbira jellemző, hogy Kanadát a kulturális és tudományos kapcsolatok terén nagy lehetőségnek tekintették. Rosta Endre 1970-ben járt Kanadában, ahol megnyitotta az „Ember és világa” című kiállítást és több más program mellett Selyével is találkozott. Az útról készült jelentésben írják: „Kanada iránti érdeklődésünket indokolja az a körülmény, hogy Kanadában megszerezhetô mind a tudományos és a tudományos-múszaki ismeret, ami az USA-ban az állami korlátozó intézkedések miatt csak nagy erőfeszítés árán, ugyanakkor Kanada politikai légköre kedvezőbb és a kétoldalú kapcsolatok során mi támogatni tudjuk az önálló nemzeti kultúra megteremtésére tett kanadai erőfeszítéseket” [24].

„Soha nem hagytam el Magyarországot, Magyarország hagyott el engem" - mondta gyakran tréfásan-ko- 
molyan Selye János, amikor Magyarországhoz füződő viszonyáról kérdezték. Köztudomású volt, hogy a professzort erős szálak füzték Magyarországhoz. Szülei itt éltek, édesapja, aki - mint Selye fogalmazott egyik interjújában - legtöbbször ugyan németül beszélt osztrák származású feleségével, de ahhoz ragaszkodott, hogy őt, a gyermeket magyarnak neveljék. Többször tett látogatást Magyarországon, intézetében szinte mindig dolgoztak magyar ösztöndíjasok, és az a szóbeszéd is járta, hogy mindig szívesen segítette a hozzá forduló, idegenbe szakadt honfitársait. Selye látogatásainak, magyarországi tartózkodásának, az ösztöndíjasok fogadásának meglehetősen gazdag levéltári forrása van. Nemcsak annak okán, hogy a fogadó intézmények emlékként őrizték meg az események egy-egy dokumentumát és nemcsak azért, mert állami tisztviselők is fogadták Magyarországon. A bőséges levéltári anyag az akkori állami rendszer eredménye is, hiszen jelentések, tájékoztatások tömkelege foglalkozott a külföldinek számító tudós látogatásaival, kapcsolataival.

Selye János mély benyomást tett a 60-as, 70-es évek Magyarországán mind a tudományos, mind pedig a kulturális életre. A fiatal kutatók példaképe volt. Amint Lázár György professzor - aki négy éven át várt arra, hogy megkapja az engedélyt a montreali kutatáshoz - visszaemlékezésében írja: „A tudományos kutatás iránt elkötelezett korosztályunk álmai közé tartozott találkozni egyszer Selye János professzorral, kijutni montreali intézetébe és együtt dolgozni vele. [...] Szemünkben már akkor, ismeretlenül is, ő volt a Kutató, a kreativitás, eredetiség megtestesítője” [25].

Mindent egybevetve, a Selye János magyar kapcsolatait tartalmazó iratok további feltárása minden bizonnyal tartogat még érdekes, izgalmas adatokat számunkra.

Anyagi támogatás: A közlemény megírása anyagi támogatásban nem részesült.

A cikk végleges változatát a szerző elolvasta és jóváhagyta.

Érdekeltségek: A szerzőnek nincsenek érdekeltségei.

\section{Irodalom}

[1] Bertók, L.: Hans Selye the investigator. In: Vince, J. (ed.): Remember our physicians. [Selye János a kutató. In: Vince, J. (szerk.): Emlékezzünk orvosainkra.] NDP Kiadó, Budapest, 2009. [Hungarian]

[2] Selye, J.: The stress of life. [Életünk és a stressz.] Akadémiai Kiadó, Budapest, 1964. [Hungarian]

[3] Curling, T. B.: On acute ulceration of the duodenum in cases of burns. Med. Chir. Trans., 1842, 25, 260-281.

[4] Kenéz, J.: Hans Selye is 55. [Hans Selye 55 éves.] Orv. Hetil., 1962, 103(3), 125-127. [Hungarian]

[5] Rácz, K., Tóth, M. (eds.): Chapters from the history of Hungarian endocrinology. [Fejezetek a magyar endokrinológia történetéből.] Semmelweis Kiadó, Budapest, 2012. [Hungarian]
[6] Karády, I., Selye, H., Browne, J. S.: The influence of "alarm-reaction" on the experimental anaphylaxis. $[\mathrm{Az}$,alarm-reactio" hatása a kisérleti anaphylaxia lefolyására.] Orv. Hetil., 1938, 82, 681-683. [Hungarian]

[7] Karády, I.: On alarm-reaction. [Az alarm-reactióról.] Orv. Hetil., 1940, 84(11), 127. [Hungarian]

[8] Szállási, Á.: Hans Selye was born 105 years ago. [105 éve született Selye János.] www.orvostortenet.hu [Hungarian]

[9] Halmágyi, D., Felkai, B., Iványi, J.: The role of hypophysis-adrenal system in the pathomechanism of chronic cardiac failure. [A hypophysis-adrenalis rendszer szerepe az idült szívelégtelenség pathomechanizmusában.] Orv. Hetil., 1951, 92(10), 293295. [Hungarian]

[10] Kovács, K., Korpássy, B.: The influence of protein-inhalt of the nutrition on hypophyseodrenocortical system and lymphatic organs in rats being in normal and alarm-status. [Az étrend fehérjetartalmának hatása normális és vészreakcióban levő patkányok hypophyseoadrenocorticalis rendszerére és lymphaticus szerveire.] Orv. Hetil., 1952, 93(1), 1-5. [Hungarian]

[11] Braun, S., Komor, K.: Non-hypertensive nephrosclerosis; contribution to the role of adrenals in hypertension. [Anhypertoniás nephrosclerosis.] Orv. Hetil., 1953, 94(11), 302-305.

[12] Arató, E.: Sport and stress. [Sport és stress.] Orv. Hetil., 1953, 94(2), 55. [Hungarian]

[13] Hetényi, G.: Pavlov Days in Leipzig in 1954. [Az 1954. évi lipcsei Pavlov-napok.] Akadémiai Értesíto, 1954, 61(503), 30-33. [Hungarian]

[14] Selye, J., Bajusz, E.: Recent progress in stress research and the role of stress theory in modern pathophysiological experimental work. I. What is stress? [A stress-kutatás újabb eredményei és a stress-elmélet szerepe a modern kórtani munkában.] Orv. Hetil., 1960, 101(1), 1-12. [Hungarian]

[15] Archive of the Hungarian Academy of Sciences. [Magyar Tudományos Akadémia Levéltára.] President, 84/4/32 d. [Hungarian]

[16] Waltner, J.: Selye professor's lecture on calciphylasis. [Selye professzor előadása a calciphylaxisról.] Orvosegyetem, 1965, 9(20), 2. [Hungarian]

[17] Anonymous: The name of Szombathely is highly appreciated overseas as well. A popular speech of Prof. Selye in the county town. [Szombathely neve a tengeren túl is tiszteletnek örvend. Selye professzor nagysikerú előadása a megyeszékhelyen.] Vas Népe, 1968, 13(108), 1. [Hungarian]

[18] The visitor's book of Markusovszky Hospital. Hospital Archive. [A Markusovszky Kórház vendégkönyve. Kórházi Archívum.] Markusovszky Kórház, Szombathely, 1968. [Hungarian]

[19] Matos, L.: Prof. Hans Selye and the art of speech. [Prof. Selye János és az előadás múvészete.] Orvosegyetem, 1968, 12(11), 3. [Hungarian]

[20] Nikolényi, I.: A conversation with Prof. Hans Selye. [Beszélgetés dr. Selye János professzorral.] Dél-Magyarország, 1968, 58(110), 3. [Hungarian]

[21] Letter of Lóránd Bertók to Béla Boros. [Bertók Lóránd levele Boros Bélának]. Pécsi Tudományegyetem, Általános Orvosi Kar, Pécs, Archívum, 1968. [Hungarian]

[22] Hungarian State Archive [Magyar Országos Levéltár], XIX-A33b0066/3/1974/Kanada (166d). [Hungarian]

[23] Lissák, K.: Foreword. In: Selye, J.: The Stress of life. [Előszó. In: Életünk és a stress.] Akadémiai Kiadó, Budapest, 1964. [Hungarian]

[24] Hungartian State Archive [Magyar Országos Levéltár], XIX-A33-b-0066/4/1970/Kanada (105.d.). [Hungarian]

[25] Lázár, G.: Hans Selye, father of stress-research. [Selye János, a stresszkutatás atyja.] Vasváry Collection, NewsLetter, 2007, 37. [Hungarian]

(Szabó Katalin dr., Budapest, Apród u. 1-3., 1013 e-mail: szabokatalin@semmelweis.museum.hu) 